\title{
Ozone bleaching of woven cotton fabric
}

\section{Pamuklu dokuma kumaşın ozonla ağartılması}

\author{
Semiha EREN ${ }^{*}$ iD , Idil YETISSİR ${ }^{2}$ iD \\ 1Textile Programme, Orhangazi Yeniköy Asil Çelik Vocational College, Uludağ University, Bursa, Turkey. \\ semihaeren@uludag.edu.tr \\ ${ }^{2}$ Textile Engineering Department, Engineering Faculty, Uludağ University, Bursa, Turkey. \\ idilyetisir@yahoo.com
}

Received/Geliș Tarihi: 21.12.2016, Accepted/Kabul Tarihi: 14.06.2017

doi: $10.5505 /$ pajes.2017.82231

* Corresponding author/Yazıșllan Yazar Research Article/Araștırma Makalesi

\begin{abstract}
In this study, the effectiveness of ozone as an alternative bleaching agent to hydrogen peroxide was investigated for cotton bleaching. The conventional method for cotton bleaching uses hydrogen peroxide, therefore; hydrogen peroxide bleaching was applied for preparing control samples. Ozone treatment were applied on the fabric for 2 different temperatures $\left(30{ }^{\circ} \mathrm{C}-80{ }^{\circ} \mathrm{C}\right)$ and one treatment time (30 minute). The whiteness/yellowness, desizing, tensile strength, weight loss (\%), COD (Chemical Oxygen Demand) values were tested and reported. Considering the whiteness/yellowness and desizing values of $30^{\circ} \mathrm{C}-30^{\prime}$ and $80^{\circ} \mathrm{C}-30^{\prime}$, the $30^{\circ} \mathrm{C}-30^{\prime}$ values were better than $80^{\circ} \mathrm{C}-30^{\prime}$ values. The reason is probably the less solubility of ozone gas at elevated temperatures. Conventional peroxide bleaching yielded higher whiteness values at the studied circumstances however the COD values were much less for ozone treatment. These values of the hydrogen peroxide were less suitable for the ecological approach compared to ozone treatment.
\end{abstract}

Keywords: Finishing, Bleaching, Ozone, Hydrogen peroxide, Ecologic

Öz

Bu çalıșmada; pamuklu kumașların ağartılmasında hidrojen peroksit ile ağartmaya alternatif olarak ozon gazı ile ağartmanın etkinliği araştırılmıştır. Pamuk ağartmada geleneksel yöntem hidrojen peroksit ağartması olduğundan kontrol numunelerinin hazırlanmasında bu yöntem kullanılmıștır. Ozon denemeleri 2 farklı sıcaklıkta $\left(30^{\circ} \mathrm{C}-80^{\circ} \mathrm{C}\right)$, tek süre (30 dk.) ile uygulanmıstır. Beyazlık/sarılık, hasıl sökme, kopma dayanımı, \% ağırlık kaybı, KOİ (Kimyasal Oksijen İhtiyacı) değerleri test edilmiș ve raporlanmıștır. $30^{\circ}-30^{\prime} \mathrm{da}$ ișlem gören numunelerin beyazlık/sarılık, haşıl sökme değerlerinin $80{ }^{\circ} \mathrm{C}-30^{\prime} \mathrm{da}$ işlem gören numunelerden daha iyi olduğu görülmüştür. Bunun muhtemel sebebi ozon gazının yüksek sıcaklıklarda çözünürlügü̈nün düsmesi olarak yorumlanmıştır. Klasik hidrojen peroksit ağartması ile deneylerde calıșılan sartlarda daha yüksek beyazlıklara ulașllmıstır ancak KO değerleri ozon işlemleri için çok daha düşük çıkmıştır. Hidrojen peroksit ağartmasındaki değerler ekolojik açıdan ozon muamelesine göre daha az uygun çıkmıştır.

Anahtar kelimeler: Terbiye, Ağartma, Ozon, Hidrojen peroksit, Ekolojik

\section{Introduction}

Cotton is generally processed in fabric form during textile finishing. Conventional preparation sequence for woven cotton fabric include singeing, desizing, scouring, bleaching and sometimes mercerization processes which consume considerable amounts of energy, water and chemicals [1],[2].

Bleaching is essential if high quality white goods are being produced, or if the goods will be dyed with pale bright colors. The aim of bleaching is to progress the whiteness of the textile material by decomposition of the yellow-brown pigments present on cotton fiber as well as removing the seed fragments. Conventional cotton bleaching most often entail hydrogen peroxide $\left(\mathrm{H}_{2} \mathrm{O}_{2}\right)$. Hydrogen peroxide bleaching of cotton requires high temperatures (up to boil), activator (usually caustic soda), stabilizer and subsequent washing in order to remove excess hydrogen peroxide. Hydrogen peroxide bleaching of cotton is basically an oxidative process and theoretically it can be substituted by other oxidative agents. Ozone $\left(\mathrm{O}_{3}\right)$ comes forward at this respect with its high oxidation potential [3]-[6].

The oxidation potential of ozone is $2.07 \mathrm{~V}$ although the oxidation potential of hydrogen peroxide is $1.77 \mathrm{~V}$. Hence, ozone can be used to oxidize many inorganic and organic impurities. Ozone's high oxidizing capacity also enables the use of ozone gas for bleaching of cotton fabrics. The main advantages associated by ozone bleaching are reported as energy and water savings and reduction of the environmental impact. [6]-[11].

Ozone is used by various industries such as wood (pulp bleaching), food, odor removal, water and wastewater treatment because of its environmental, economic and effective benefits. However, industrial application of ozone at textile is limited by denim washing despite ozone's benefits. Large scale denim washing machines equipped by ozone generators are present on the market and these are mainly used to remove the back staining of denim goods. Much effort is being spent on utilization of ozone for textile finishing. Researchers reported successful laboratory practices on: washing of dyed polyester at which conventional reductive clearing was substituted by ozone clearing resulting almost $84 \%$ savings [12]-[16]; bleaching of cotton where whiteness of the cotton samples were increased by ozone treatment and compared to conventional peroxide bleach [6],[21]-[23]; treatment of PLA (polylactic acid) at which physical properties of PLA fabrics were tested and reported [17]; treatment of soybean to examine the effects of ozone treatment on soybean properties [18]; bleaching of rabbit [19] and wool [20] fibers and also dye stripping of reactive dyed cotton in which dye stripping and redyeing into black was successfully achieved for seven type of reactive dyes with various reactive and chromophore groups [24].

This successful literature highlighted ozone by energy and time savings and environmental load reduction owing to low 
temperature requirement of ozone processes and substitution of conventional harsh chemicals by ozone. [24] This is in agreement with todays environmental awareness and environment protection approach.

In this study, ozone treatment was tested for bleaching of cotton goods. The novelty of the study stands on the treatment temperatures. It is known that the solubility of ozone decreases by increasing the temperature until $40-45^{\circ} \mathrm{C}$ and ozone is not dissolved in water above these temperatures. Also, the half-life of ozone decrease at elevated temperatures. On the other hand, the reactions of ozone increase by increasing the temperature. However, gaseous ozone is also capable of oxidizing substances. However, ozone treatment studies are usually performed at room temperatures regarding the solubility and decreased halflife. In this study, ozone treatment was not only applied at cold temperatures $\left(30^{\circ} \mathrm{C}\right)$ but also at hot $\left(80^{\circ} \mathrm{C}\right)$ temperatures.

\section{Experimental}

\subsection{Materials}

Woven fabrics, constructed from, $100 \%$ cotton yarns of $\mathrm{Ne}$ $60 / 1(110 \mathrm{~g} / \mathrm{m} 2)$ were used in this study. Fabrics were provided by Megrel Textile INC./Bursa, Turkey. Starch sizing agent was present on the fabrics.

A Prodozon PRO D025 model ozone generator (Peksenel Co., Ankara, Turkey) with a maximum ozone generation capacity of $25 \mathrm{~g} / \mathrm{h}$ was used during the experiments. The gas low rate was adjusted to $5 \mathrm{l} / \mathrm{h}$ via a flowmeter. The outlet gas of the ozone generator was injected to the liquor circulation line of a sample Atac BB01F sample dyeing machine (Atac Co., Istanbul, Turkey) via a venturi injector. All connections were made by teflon tubing lines. The experimental device is given on Figure 1.

A Konica Minolta CM3600d spectrophotometer (Konica Minolta Inc., Tokyo, Japan) was used for color (whiteness/yellowness) measurements. An Instron model 4301 (Instron, High Wycombe, UK) device was used for tensile tests. A UV-vis spectrophotometer (Merck Pharo 300 Spectroquant; Merck, Darmstadt, Germany) and a thermoreactor (WTW CR 2200; WTW, Weilheim, Germany) were used during COD testing.
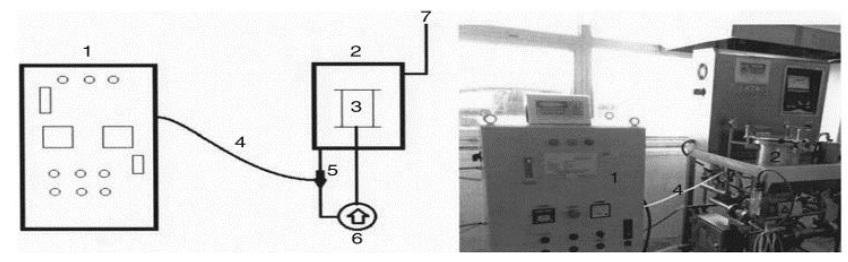

Figure 1: Ozone integrated sample dyeing machine: 1-Ozone generator; 2-Dyeing chamber; 3-Beam; 4- Ozone flow line; 5-Venturi injection; 6-Circulation pump; 7-Exhaust ozone line. [24].

\subsection{Methods}

Conventional hydrogen peroxide bleaching and ozone treatments were applied for bleaching of cotton.

Hydrogen peroxide bleaching was applied to the greige cotton fabrics as the conventional reference treatment. The hydrogen peroxide bleaching recipe was;
$2 \mathrm{~g} / \mathrm{l} \mathrm{NaOH}$

$2 \mathrm{~m} / \mathrm{l} \mathrm{H}_{2} \mathrm{O}_{2}(\% 50)$

$2 \mathrm{~g} / \mathrm{l}$ surfactant (non-ionic)

$0.8 \mathrm{~g} / \mathrm{l}$ stabilizer (organic stabilizer)

The peroxide bleaching process was performed at $95{ }^{\circ} \mathrm{C}$ for 45 minute.

Ozone treatments for bleaching of greige cotton were applied at two temperatures $\left(30^{\circ}-80^{\circ} \mathrm{C}\right)$ and for 30 minutes, in neutral water at room temperature without use of any chemicals. The treatment time was chosen according to literature [8].

All treatments were repeated three times.

\section{$2.3 \quad$ Tests}

Desizing degree was measured by dropping $\mathrm{I}_{2} / \mathrm{KI}$ solution onto the samples to grade the color with the Tegewa scale. Tegewa scale ranking is from 1 to 9 where 9 is the best degree indicating there is no residual starch size on the fabric.

Whiteness and yellowness of the samples were measured via a spectrophotometer. Stensby values of the cotton samples were determined as whiteness formula. Each sample was measured from four different areas, twice on each side of the fabric for consistency, and the average value was calculated.

COD evaluations were made according to the standard titrimetric method (Standard Methods 5220 C: Closed Reflux, Titrimetric Method, APHA, 19th edn, American Public Health Association, 1995).

Tensile Strength tests were performed according ISO 13934:1999 on an Instron model 4301 testing device.

Weight Loss (\%) tests were performed according to the equation 1 ;

$$
\text { Weihgt Loss }(\%)=\frac{W_{0}-W_{1}}{W_{0}} * 100
$$

$W_{0}=$ Untreated Fabric, $W_{1}=$ Treated Fabric.

\section{Results and discussion}

\subsection{Whiteness and yellowness evaluation}

The whiteness values of the samples are given on Figure 2 and the yellowness values are given on Figure 3 after respective treatments.

Figure 2 indicates that the whiteness of the samples increased either by ozone treatment or by peroxide bleaching. The highest whiteness value was reached by conventional peroxide bleaching which was 86 Stensby degrees. However, ozone treatment also resulted satisfactory whiteness improvements. 30 min $30{ }^{\circ} \mathrm{C}$ ozone treatment yielded 78 Stensby degrees whiteness.

Among the ozone bleached samples; samples treated in cold water $\left(30^{\circ} \mathrm{C}\right)$ had the highest whiteness ( 86 Stensby degree) and the samples treated in hot water $\left(80{ }^{\circ} \mathrm{C}\right)$ had the least whiteness degree (70 Stensby degree).

The yellowness values presented on Figure 3 were vice versa as expected because yellowness decreases as the whiteness increase.

The reason for less whiteness (and high yellowness) at elevated temperatures may be attributed to poor dissolution of ozone at elevated temperatures. Literature reports that ozone solubility 
in water diminishes above $40-45^{\circ} \mathrm{C}$ temperatures [9],[25]-[27] However, there is still increase in the whiteness degrees at $80^{\circ} \mathrm{C}$ treatments indicating that gaseous ozone is also effective during the treatments.

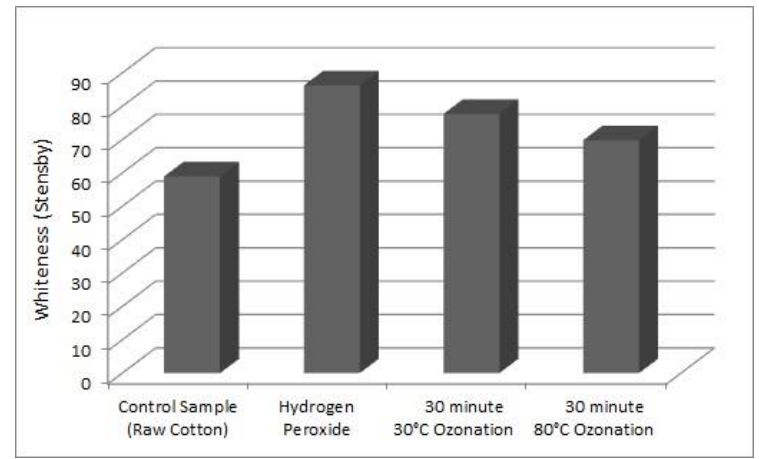

Figure 2: Whiteness (Stensby) values of the samples.

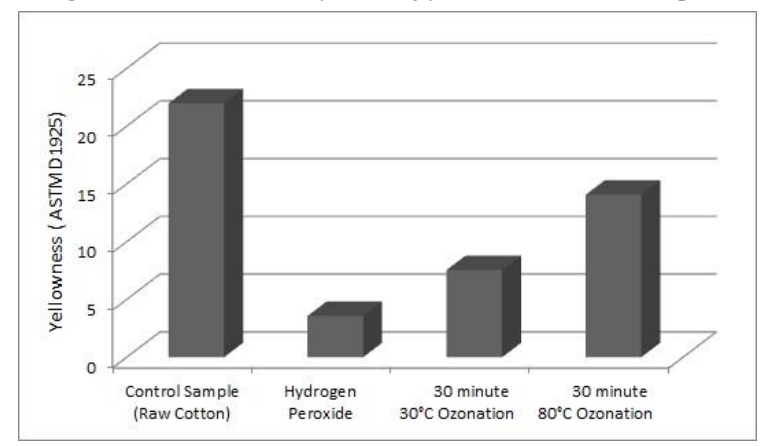

Figure 3: Yellowness (ASTM D 1925) values of the samples.

\subsection{Desizing effect evaluation}

Bleaching is an oxidative process, desizing simultaneously occurs during the treatment. Starch size may be desized either by enzyme treatment (amylases) or oxidation. The desizing degrees after respective treatments are given on Figure 4.

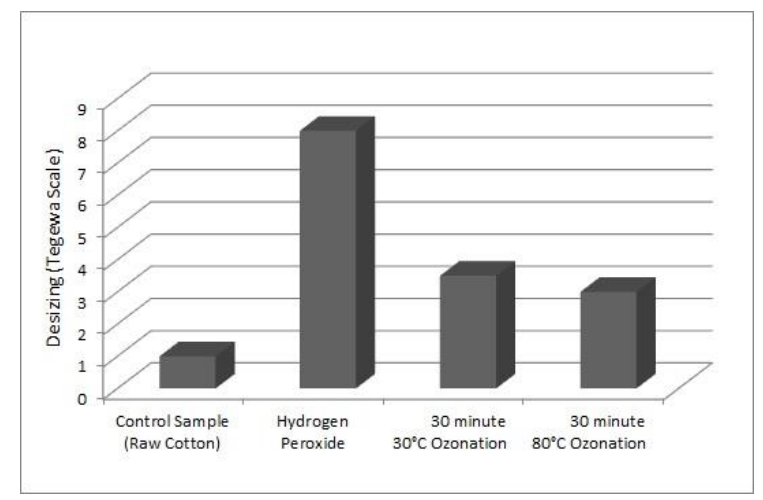

Figure 4: Desizing degrees (according to Tegewa scale) after respective treatments.

In fact the main purpose of bleaching is to improve whiteness not desizing, but desizing simultaneously occurs during the treatment. Desizing degree is measured by dropping $\mathrm{I}_{2} / \mathrm{KI}$ solution onto the samples to grade the color with the Tegewa scale. Tegewa scale ranking is from 1 to 9 where 9 is the best degree indicating there is no residual starch size on the fabric. As seen on Figure 4 most of the sizing agents were removed during conventional peroxide bleaching with an average Tegewa rating of 7.5 although the ratings were $2-4$ for ozone treated samples. The difference may be because of the harsh alkaline circumstances accompanied by high temperatures at $95^{\circ} \mathrm{C}$ conventional peroxide bleaching. Considering the ratings were 1 for untreated samples, it can be concluded that ozone treatment helps to remove some portion of starch size from the fabric but conventional peroxide bleaching is more successful at this respect.

\subsection{Tensile strength evaluation}

Oxidative processes can damage cotton to decrease its strength. Therefore tensile strength of the samples was measured and results are presented on Figure 5. Figure 5 indicates a decrease on the tensile properties after ozone treatments compared to conventional peroxide bleaching.

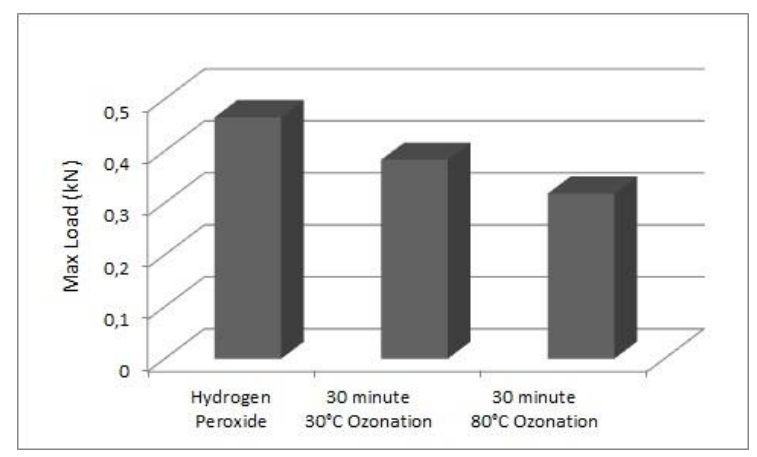

Figure 5: Tensile strength $(\mathrm{kN})$ of the samples.

\subsection{Weight loss \% evaluation}

Weight loss \% of the samples were measured and results are presented on Figure 6.

Approximately 9\% weight losses were observed on samples. The fabric samples were greige and starch sizing agent was present on the fabric samples. As given on Figure 4, some portions of sizing agent were removed from the fabric after respective treatments. Hence, the weight loss observed on the samples is mainly because of removal of sizing agent. The weight loss observed on $30 \mathrm{~min}-80{ }^{\circ} \mathrm{C}$ treated samples were higher compared to $30 \mathrm{~min}-30^{\circ} \mathrm{C}$ treated samples. The higher weight loss of 30 min- $80{ }^{\circ} \mathrm{C}$ treated samples may be attributed to higher treatment temperature which usually aids extraction of impurities.

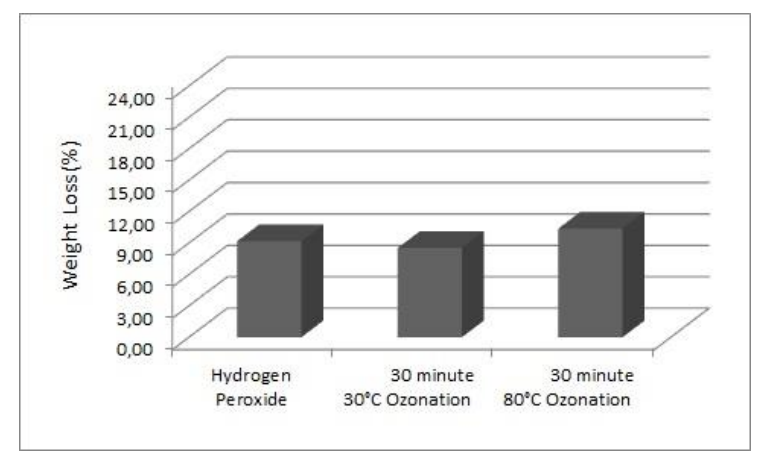

Figure 6: Weight Loss (\%) of the samples.

\subsection{Environmental impact evaluation}

Environmental impact of the textile wet processes is of importance nowadays. Therefore, COD of the process effluents were measured for ozone treatments and conventional peroxide bleaching. Results are given on Figure 7.

It is clear that there is a substantial decrease in the COD values of the processes in case of ozone treatments. Because there is 
not any harsh chemical in the ozone treatment bath. Ozone treatments were performed in neutral water without use of any chemicals. Also ozone itself decomposes into oxygen Therefore COD values of the ozone treatment baths $(25-30 \mathrm{mg} / \mathrm{l})$ are much less compared to the COD values of conventional peroxide bleaching effluent (1338 $\mathrm{mg} / \mathrm{l})$.

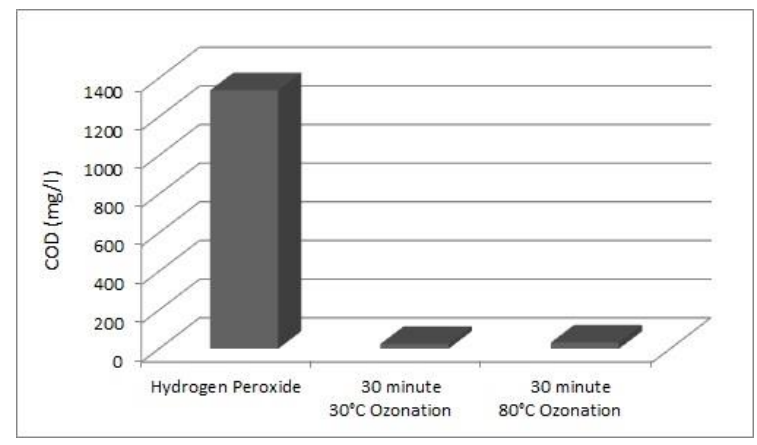

Figure 7: $\operatorname{COD}(\mathrm{mg} / \mathrm{l})$ results.

\section{Conclusion}

In this study, bleaching of cotton with ozone, instead of conventional hydrogen peroxide bleaching was examined.

Results indicated that:

- $\quad$ Ozone increases whiteness of the fabric and decreases the yellowness,

- Conventional peroxide bleaching yielded higher whiteness values at the studied circumstances,

- Ozone treatment helped to remove some portion of starch sizing agent from the fabric.

Ozone treatment effluent has much less COD values compared to conventional peroxide bleaching effluent.

\section{References}

[1] Choudhury AR. Textile Preparation and Dyeing. New Hampshire, USA, Science Publishers, 2006.

[2] Broadbent AD. Basic Principles of Textile Coloration. West Yorkshire, United Kingdom, Society of Dyers and Colourists 2001.

[3] Tarakçıŏlu I. Tekstil Terbiyesi ve Makineleri. İzmir, Türkiye, Ege Üniversitesi Matbaası, 1986.

[4] Çoban S. Genel Tekstil Terbiyesi ve Bitim Isşlemleri. İzmir, Türkiye, Ege Üniversitesi Matbaası, 1999.

[5] Aniș P. Tekstil Ön Terbiyesi. Bursa, Türkiye, Alfa Kitabevi, 1998.

[6] Eren HA, Ozturk D. "The evaluation of ozonation as an environmentally friendly alternative for cotton preparation". Textile Research Journal, 81(5), 512-519, 2011.

[7] Eren HA, Kurcan P, Anis P. "Investigation of the effects of dye hydrolysis on decolorisation of reactive dyeing effluents by ozonation". Tekstil ve Konfeksiyon, 17(2), 119-125, 2007.

[8] İnkaya T, Eren HA, Aniş P. "Pamuk ağartilmasinda lakkaz/mediatör sistemlerinin oksijen ve ozon ile kombine edilmesi". Pamukkale Üniversitesi Mühendislik Bilimleri Dergisi, 14(1), 77-82, 2010.
[9] Öztürk D, Eren HA. "Tekstil terbiyesinde ozon kullanimi”. Uludağ Üniversitesi Mühendislik-Mimarlık Fakültesi Dergisi, 15(2), 37-51, 2010.

[10] Perincek S, Duran K, Korlu A. Bahtiyari I. "An investigation in the use of ozone gas in the bleaching of cotton fabrics". Ozone: Science Engineering, 29, 325-333, 2007.

[11] Prabaharan M, Rao JV. "Study on ozone bleaching of cotton fabric process optimization, dyeing and finishing properties". Coloration Technology, 117(2), 98-103, 2001.

[12] Eren HA. "After clearing by ozonation: a novel approach for disperse dyeing of polyester". Coloration Technology, 122(6), 2006.

[13] Eren HA. "Simultaneous after clearing and decolonization by ozonation after disperse dyeing of polyester". Coloration Technology, 123(4), 224-229, 2007.

[14] Eren HA, Ozturk D, Eren S. "After clearing of disperse dyed polyester with gaseous ozone". Coloration Technology, 128(2), 75-81 2012.

[15] Gundogan S. Eren, HA. "Practical realization of ozone clearing after disperse dyeing of polyester". Coloration Technology, 130(5), 357-362, 2014.

[16] Eren HA, Gundogan S, Eren S, Kocaman B. "Substitution of reduction clearing step by ozone treatment at disperse dyeing of polyester". Ozone: Science \& Engineering, 35(3), 196-200, 2013

[17] Avinc 0, Eren HA, Uysal P. "Ozone applications for afterclearing of disperse-dyed poly (lactic acid) fibres". Coloration Technology, 128(6), 479-487, 2012.

[18] Avinc 0, Eren HA, Uysal P. Wilding M. "The effects of ozone treatment on soybean fibers". Ozone: Science \& Engineering, 34(3), 143-150, 2012.

[19] Perincek S, Bahtiyari MI, Körlü AE, Duran K. "Ozone treatment of Angora rabbit fiber". Journal of Cleaner Production,16(17), 1900-1906, 2008.

[20] Gülümser T, Akça C, Bahtiyari Mİ. "Yün terbiyesinde ozonla işlemin beyazlik derecesine etkisinin araştirilması". Journal of Textile \& Apparel/Tekstil ve Konfeksiyon, 19(1), 52-55, 2009.

[21] Piccoli HH, Ulson de Souza AA, Ulson de Souza SMAG. "Bleaching of knitted cotton fabric applying ozone". Ozone: Science \& Engineering, 37(2), 170-177, 2015.

[22] Arooj F, Ahmad N, Chaudhry MN. "A pilot-scale application of ozone to bleach raw cotton fabric using various additives". Ozone: Science \& Engineering, 37(3), 203-215, 2015.

[23] Perincek SD, Duran K, Korlu AE, Bahtiyari İM. "An investigation in the use of ozone gas in the bleaching of cotton fabrics". Ozone: Science and Engineering, 29(5), 325-333, 2007.

[24] Eren S, Gümüs B, Eren HA. "Colour stripping of reactivedyed cotton by ozone treatment". Coloration Technology, 132(6), 466-471, 2016.

[25] Oğuz E, Çelik Z. "Suların ozonlanmasindaki gelişmeler". Pamukkale Üniversitesi Mühendislik Bilimleri Dergisi, 7(3), 367-372, 2001.

[26] Ozon "Ozone Proporties". http://www.ozoneapplications.com/info/Ozone\%20Solu tions\%20MSDS\%200zone.pdf (11.12.2018)

[27] Lenntech. "Ozone decomposition". http://www.lenntech.com/library/ozone/decomposition /ozone-decomposition.htm (10.02.2018). 